\title{
Esboço de uma introdução ao estudo da língua Tupí
}

Aryon Dall'Igna Rodrigues

\section{Os Tupinambá e sua Distribuição nos Séculos XVI e XVII}

1. Sob o nome Tupinambá são designados atualmente todos os índios que, falando uma língua Tupí-Guaraní, ocupavam, nos séculos XVI e XVII, o litoral brasileiro, desde a foz do Amazonas, ao norte, até Cananéia, ao sul (cf. Métraux, "The Tupinamba", p. 95). Estes índios, embora estreitamente aparentados linguística e culturalmente, dividiam-se em numerosas tribos, que faziam guerra entre si, e que ficaram conhecidas por diferentes nomes, dos quais o mais comum é Tupinambá, que ocorria no Maranhão, na Bahia, no Rio de Janeiro.

2. Assim são especificadas essas tribos por Métraux, segundo as informações dadas nas fontes quinhentistas e seiscentistas ("La Civilisation Matérielle des Tribus Tupi-Guarani”, pp. 12-19; “The Tupinambá”, pp. 95-97): Tupinambá em toda a costa entre os rios Pará (Tocantins) e Parnaíba, e ao longo dos rios Pindaré, Mearim e Itapicuru; Potiguara no litoral entre os rios Parnaíba e Paraíba e no interior até as serras de Copaoba e Ibiapaba; Caetê na costa entre os rios Paraíba e São Francisco; Tupinambá do rio São Francisco a Camamu; Tupinikin de Camamu até o rio São Mateus ou Cricaré; Temiminó ao sul do Estado do Espírito Santo e no baixo curso do rio Paraíba; Tupinambá (ou Tamoio) do cabo de São Tomé até Angra dos Reis; Tupinakin (ou Tupí ou Tabaiara) de Angra dos Reis a Cananéia. No interior são assinalados: Tabaiara ou Tobajara, primeiramente na Serra de Ibiapaba (Serra Grande do Ceará), depois emigrados para o alto Mearim, no Maranhão; Tupina, a oeste dos Caeté, Tupinambá e Tupinikin, estendendo-se do norte do Rio São Francisco até Camamu; Amoipira - ramo dos Tupinambá - à esquerda do rio São Francisco, no interior da Bahia; além de outras tribos cuja localização não pode ser bem determinada (Viatan, Apiapitanga, Muriapitanga, etc.). 


\section{A Cultura Material e Espiritual dos Tupinambá}

3. Os Tupinambá viviam em aldeias (tába) constituídas de 4 a 8 grandes casas comuns (óka), de formato retangular e de teto abobadado, que se prolongava até ao chão, formando, assim, as paredes laterais; este teto e parede era feito com folhas, trançadas, de palmeira pindoba (pindóba) ou pati (patíóba), ou com folhas de tábua, uma tifácea (kapára: Typha dominguensis Pers. ?), sobre uma armação de madeira, com os esteios principais (ókytá) fincados no chão. Em cada extremidade da casa, e no meio da parede lateral, havia uma porta muito baixa (ókéna). Em média essas casas tinham 75 a $90 \mathrm{~m}$. de comprimento, 9 a 15 de largura e 3,5 de altura, e abrigavam cerca de 30 famílias, i. é, mais de 100 pessoas, às vezes até 200 . As casas eram dispostas em torno de uma praça retangular (ókára), na qual se desenvolvia a vida social e religiosa do grupo (cada tribo compreendia numerosos grupos, vivendo cada qual numa aldeia). As aldeias eram situadas em colinas, expostas ao vento, nas proximidades de cursos d'água e de terras cultiváveis. Cada 4 ou 5 anos, quando o solo de suas roças ( $k o ́$ ) estava exausto, ou começava a estragar-se a cobertura das casas, os Tupinambá mudavam a aldeia para um lugar próximo, aproveitando, em geral, o material empregado na edificação da primeira e conservando-lhe o nome. Quando sujeitas ao ataque de inimigos, as aldeias eram protegidas por duas cercas (ybyrá), a externa (ybyrápokánga) formada por grossos palanques pontudos fincados no chão, a certa distância um dos outros; a interna (ybyrápataguî) constituída por troncos de palmeira bem unidos uns aos outros, apenas com as necessárias portas e seteiras.

4. Dentro da óka, cada família ocupava o espaço compreendido entre dois esteios das paredes laterais, e não havia paredes divisórias. As rede de dormir (inî), principais peças do mobiliário, eram presas a esses esteios ou a esteios adicionais; faziam-nas de algodão (amyniiú), com punhos de fibras vegetais. Atravessando varas sobre os caibros de sua parte da casa, a família fazia um jirau, sobre o qual guardava seus bens: cuias (kúia), potes (kamusí, ygasába), cestos (panakú), peneiras (urúpéma), armas, mantimentos, etc. Cada família mantinha, em sua repartição, um fogo aceso dia e noite, o qual, durante a noite, protegia contra o frio e contra os mosquitos (borrachudos: piru(n), pernilongos: nhatiu(n)). Outra peça do mobiliário tupinambá era um banquinho de madeira (apykába). Às vezes comiam sobre estrados (pataguî).

5. Os Tupinambá não vestiam nenhuma roupa. Usavam, porém, muitos ornamentos. Chapéus de penas vermelhas, amarelas ou verdes (akángaóba), diademas (akángatára) feitos com penas de garça vermelha (guará) ou de canindé (kanindê), colares, braceletes e enfeites para as pernas e notáveis mantos de plumas de garça vermelha (guaráábusú), tais eram os mais comuns ornamentos de penas. Principalmente os chefes e homens importantes tinham colares de conchas, alguns até de $9 \mathrm{~m}$. de comprimento, que tinham de ser enrolados 
várias vezes em torno do pescoço; também as mulheres usavam longos colares, cujas voltas lhes cobriam o peito. Com conchas confeccionavam ainda braceletes (nhaã). Todos os homens, e só os homens, a partir dos 5 ou 6 anos de idade, levavam no lábio inferior, para esse fim perfurado, tembetás (tembetára ou mbetára) de pedras de diversas cores, especialmente, porém, os de cor verde (mbetárobý). Também os homens faziam um ou dois furos nas asas do nariz, nos quais enfiavam pedaços longos e finos de madeira ou ossinhos brancos. Tanto homens como mulheres, mas sobretudo estas, perfuravam os lobos das orelhas, para aí introduzir um enfeite de osso de macaco (nambípáia) ou um rolete de madeira enleado com fio de algodão. Davam grande importância a um crescente (iasý) feito de pedaços de conchas e de ossos que, suspenso ao pescoço por um cordão, pendia-lhes sobre o peito.

6. Extirpavam todos os pelos do corpo, inclusive os cílios e as sobrancelhas. Os homens raspavam o cabelo na testa até a altura das orelhas, utilizando-se de uma faca de taquara (kysê) ou de quartzo (itákysê). As mulheres, porém, usavam os cabelos longos e soltos sobre as costas e, para trabalhar, amarravam-nos no alto da cabeça. Tanto os homens como as mulheres se tatuavam, estas só ao alcançar a puberdade, aqueles sempre que matavam um inimigo. Também se pintavam em todas as ocasiões festivas, especialmente de preto, com o suco de jenipapo (ianypába), e de vermelho, com o suco do urucu (urukú).

7. A agricultura tinha grande importância para os Tupinambá, pois dela tiravam grande parte dos elementos para sua subsistência. Faziam roças ( $k o ́)$, derrubando as árvores na floresta, próximo às aldeias, com machados de pedra (jý), e depois queimando-as. Este trabalho era realizado pelos homens. A plantação e a colheita, porém, faziam-nas as mulheres. A principal planta cultivada para a alimentação era a mandioca, em suas espécies amarga (mandíýba) e doce (aipî), das quais conheciam e distinguiam 24 variedades (mandíýbusú, mandíytínga, mandí́paratá...; aipíguasú, aipímakaxéra, aipíiurumu, aipípitínga...). Depois da mandioca, de maior importância era o milho (abatî), de que conheciam diversas variedades. Outras plantas cultivadas para a alimentação: cará (kará), mangará (mangará), taiá (taiá), batata doce (ietýka), fava (komandá), feijão (komandámiri(n), abóbora (iurumú), amendoin (mundubi), abacaxi (naná), pimenta (kyýia, kyýnha). Logo após a chegada dos europeus, adotaram e passaram a cultivar em grande escala a banana (pakóba); também a cana de açúcar (takuáree(n), uúbee(n)). Para outros fins, que não a alimentação, cultivavam ainda o algodoeiro (amyniiúýba), ao qual aplicavam a poda, o cabaceiro (kuieté), o fumo (petýma), o urucuzeiro (urukú), provavelmente o jenipapeiro (ianypába).

O plantio das sementes era feito em uma cova obtida com um pau que fazia às vezes de enxada (sýra). 
8. Alimentavam-se, ainda, os Tupinambá de plantas silvestres, especialmente dos frutos, em grande quantidade: caju (akaiú), mangaba (mangába), sapucaia (iasapukáia), araçá (arasámiri(n)), goiaba (araságuasú), araticum (aratikú), jaboticaba (iabotíkába), acajá (akaiá), ingá (ingá), bacupari (ybákuruparî), piqui (pikî), piquiá (pikiá), oiti (guitî), pindóba (pindóba), ouricuri (urukurî).

Coletavam também para a alimentação mel (eýra), ovos de guará (guarárupiá), ostras (rerî) formigas (ysá).

9. Outras fontes de subsistência eram a caça e a pesca. A caça era feita especialmente com arco (ybyrápára ou guyrápára) e flechas (uúba). O arco era confeccionado com madeira de pau-d'arco (guyrápárýba), jacarandá (iakarandá), sapucaia (iasapukáia) ou palmeira airi (airí), e a corda (sáma) era de algodão (amyniiú) ou de fibra de tucum $(t u k u(n))$; as flechas eram feitas de cana sem nós (uúba), com ponta de taquara (takuára), de osso (kánga), de dente de animal, de esporão da cauda da raia ou de madeira dura. Apanhavam a caça também com armadilhas como mundéus (mundé), laços (iusána), etc. Entre os animais que caçavam para comer, citam-se as várias espécies de veados (syguasú), porcos do mato (taiasú, taytetú, iapurútere(n)), macacos (kaí, kaíguasú), cotia (akutî), paca (páka), tatus (tatú), anta (tapyýra), pombos (pykasú), jacu (iakú), jacutinga (iakútínga), mutum (mutu(n)), etc.

A pesca também era feita com arco e flecha; além disto serviam-se para ela de redes (pysá; para camarões: iareré), de anzóis (pindá), do suco tóxico de timbó (timbó) e de tingui (tingul), e de vários outros sistemas, como o cerco do rio, a pesca noturna com o auxílio de tochas (ysýsaýguasú), a apreensão do peixe com as próprias mãos, a nado.

10. A raiz da mandioca (mandióka) era ralada num ralo (ybese $(n)$ ), depois colocada no tepiti (tepitî), prensa constituída por um tubo extensível, com que se lhe extraía o sumo venenoso (manípuéra); depois de espremida, a massa era passada numa peneira (urúpéma) e então seca e feita farinha (uî), a qual se não era bem seca, mas mole, constituía a "farinha ralada" (uitínga), se mais seca era a uíesakuátínga e, se bem seca, a "farinha de guerra" (uíatã). Da farinha seca misturada com água, obtinha-se uma massa que, assada, constituía o beiju (mbeiú). O suco da mandioca, em descanso, deixa assentar o amido (typýóka ou typýáka), que, seco, constitui a farinha de tapioca (typýókuî). Outro modo de aproveitar a mandioca era deixar os tubérculos na água, durante alguns dias, até ficarem moles (mandiópúba), o que, depois de seco, constituía a carimã (kaarimã), de que se obtinha uma farinha (kaarimãkuî). Com a farinha de carimã e água fazia-se o mingau (mingaú), que se temperava com pimenta (kyýia). Também faziam farinha de mandiópúba, e esta era a chamada "farinha d'água" (uípúba). 
Outros tubérculos - cará, taiá, batata, mangará - eram cozidos ou assados. O milho era transformado em farinha (abatíuî), se não também cozido ou assado. A carne de caça (soó) e o peixe (pirá) eram igualmente assados ( $m i-$ xýra) ou cozidos (mimóia). Os peixes pequenos eram também assados sob as cinzas, envoltas e folhas (mimokéka). Para conservar por muitos dias a carne, moqueavam-na, i. é, assavam-na a fogo lento, durante cerca de 24 hs., sobre uma grelha de madeira $(\operatorname{mokae}(n))$. Os condimentos eram especialmente a pimenta (kyýia), de que usavam várias espécies ( $k$. apuá, $k$. kumarí, etc.) e o sal (iukýra) obtido da água do mar, ou uma mistura de ambos, chamada iukýtáia ("sal ardido").

11. As bebidas fermentadas eram de grande importância para os Tupinambá, que as denominavam em geral cauim (kaui(n)). Faziam-nas de caju (akaiúý), de aipim-macaxera (aipíy),desta havendo duas variedades, uma fermentada com saliva (kauíkarasú), outra não (kauimakaxéra); de milho (abatíý), de ananás (nanáý), de batata doce (ietýký), de banana (pakóbý), de beiju (mbeiútíngý), de tapioca (typýáký).

12. Cada óka tinha um chefe (tubixába ou morubixába), e este se subordinava ao chefe, da tába (morubixába ou tubixábeté), cuja autoridade era indiscutível em tempo de guerra, mas que, na paz, ficava sujeito à sanção dum conselho de velhos (tuíbaé), constituído pelos mais idosos e mais famosos guerreiros, que se reuniam na ókára para as decisões importantes (nhomongetá). Falava o chefe e, a seguir cada conselheiro dava sua opinião, enquanto os demais fumavam grandes cigarros. Predicados necessários para ser chefe era o valor guerreiro, poder mágico, dons oratórios e boa saúde. Todas as manhãs os chefes das casas distribuíam as tarefas a serem realizadas pelos membros de sua óka e faziam um discurso exortando o povo a trabalhar e a seguir exemplo dos antepassados (tamýipáguáma).

13. Os Tupinambá faziam guerra (guariní, marána) com bastante frequência, quer entre si, quer com outros índios. A guerra era determinada por razões diversas, sociais e religiosas, e eles só iam a ela quando certos da vitória, indicada pela interpretação de sonhos (mosausúba) ou pela prática de rituais vários. Os guerreiros pintavam o corpo e punham seus melhores enfeites de penas. Além do arco (ybyrápára) e flechas (uúba), levavam o tacape (ygapéma) e, como arma defensiva, um escudo (guarakapá) de couro de anta. O exército em marcha era acompanhado por instrumentos musicais (especialmente tambores: guarará e trombetas: mimbýapára).

14. Um dos principais objetivos da guerra era a captura de prisioneiros para o sacrifício e a antropofagia ritual. O homem que primeiro punha a mão sobre o prisioneiro (miausúba) era o seu dono. Era o prisioneiro levado para a aldeia de seus vencedores, ouvindo insultos a que respondia com altivez. $\mathrm{Na}$ aldeia, dava-se toda liberdade ao prisioneiro, que jamais procurava fugir, não 
só porque seria tido por covarde pelos seus, se a eles voltasse, mas porque tinha como a mais honrosa a morte em sacrifício ritual. A data do sacrifício, que podia dar-se meses após a captura, era fixada pelo conselho tribal. Quando ela se aproximava, faziam-se os preparativos, que requeriam muita antecedência, e convidavam-se as aldeias amigas. A corda para amarrar o prisioneiro $(\mathrm{mu}-$ surána) era confeccionada especialmente para esse fim. Preparava-se grande quantidade de cauim. No dia aprazado, de manhã, era o prisioneiro conduzido à praça por algumas velhas (guaibi(n)), entre gritos, cantos e música. A muçurana era-lhe amarrada na cintura e segura, nas extremidades, por dois ou mais homens. Aparecia o executor, todo enfeitado e seguido por seus parentes, que cantavam e tocavam tambor. Um guerreiro velho e famoso passava o tacape às mãos do executor e este, então, punha-se a falar para a vítima, escarnecendo da sua situação. O prisioneiro, porém respondia altivamente, predizendo a vingança que de si tomariam seus parentes e ufanando-se de seus feitos guerreiros. O executor devia abatê-lo com um golpe certo sobre a nuca, o que nem sempre era fácil, pois a vítima podia esquivar-se para pô-lo em ridículo. Consumada a execução, o povo todo gritava e assobiava. Logo era o corpo esquartejado e assado para o banquete (pepýra), destacando-se pela avidez as velhas. Enquanto isso, o executor corria para sua casa, em que penetrava atravessando por entre a corda e madeira de um arco, e lá continuava a correr dum lado para outro, a fim de escapar ao espírito (ánguéra) da vítima. Então recebia ele novo nome (téra), que era proclamado por suas irmãs e primas. Todas as pessoas de sua geração tomavam também novos nomes. A carne do executado era tabu para o executor, o qual, depois, devia ficar em sua rede, observando dieta especial, durante alguns dias, até que de novo crescesse cabelo em sua fronte raspada. Então se realizava outra festa, com cauim, na qual ele fazia sobre o corpo a tatuagem que assinalava seu grande feito.

15. Acreditavam os Tupinambá na existência de vários espíritos e de fantasmas. Estes eram encontrados sobretudo no mato, nos lugares escuros e na proximidade dos túmulos. Podiam tomar o aspecto de pássaro (auirá), morcegos (andirá), etc., e causavam mal aos índios, razão por que nenhum andava no escuro sem estar munido de um facho. Os espíritos eram vários, nem todos bem conhecidos atualmente: Tupána o espírito do Trovão, cuja principal função era ir de leste a oeste, provocando o trovão (tupãsunúnga), o relâmpago (tupãmberába), e a chuva (amána), e cujo nome, após o contato com os brancos, foi aplicado a Deus. Outros espíritos: Anhánga, Kurupíra, Taguaýba, Iuruparí, Taúba, Aguasaý, Guaiupyá, etc.

16. Os intermediários entre o povo e os seres sobrenaturais eram os xâmans ou pajés (paiê), dotados de poderes mágicos, cuja função era adivinhar o futuro, fazer chuva e, sobretudo, curar. Os mais poderosos eram chamados "grandes pajés" (paiéguasú) ou caraíbas (karaíba). Distinguiam-se os pajés que 
trabalhavam para o bem comum, tratando os doentes e consultando os espíritos acerca do sucesso nas guerras, na caça, etc. (paiékatú), dos que faziam feitiços (mosánga) para matar ou tornar alguém doente, dificultar a caça e a pescaria, etc. (paiéaíba ou paiéángaíba, ou, ainda, mosángiiára). O tratamento dos doentes era feito principalmente por sucção do corpo e extração de objetos a que se atribuía a causa do mal, e pelo sopro de fumaça de tabaco sobre o corpo.

\section{A língua dos Tupinambá e seu emprego pelos colonos e missionários}

17. Os Tupinambá falavam todos a mesma língua, com insignificantes variantes locais. Essa língua, a que atualmente se chama Tupí, do nome de uma das tribos tupinambás (de São Vicente), foi conhecida durante a Colônia pelos nomes de "língua geral" (dos índios do Brasil), "língua do Brasil", "língua brasílica, brasiliana ou brasileira”. Filia-se à família linguística Tupí-Guaraní, uma das maiores da América do Sul, ainda hoje representada por grande número de línguas faladas no Brasil, principalmente, e na Argentina, no Paraguai, na Bolívia, no Peru e na Guiana. Em seu aspecto exterior, isto é, fonético, é uma língua bastante harmoniosa, graças ao perfeito equilíbrio entre vogais e consoantes. Sua constituição interna apresenta um sistema morfológico algo complexo, mas muito coerente. A sintaxe, também complexa, permite relativa liberdade de expressão. A possibilidade de formar compostos e derivados com grande facilidade garante fácil e espontânea manifestação do pensamento.

18. Os colonos portugueses e franceses e os missionários, logo que chegaram ao Brasil, nos meados do século XVI, tiveram necessidade de aprender a língua dos Tupinambá, pois dada a distribuição geográfica destes, em qualquer ponto do litoral onde se estabelecessem, entravam os alienígenas em contato com alguma sua tribo. Pronto verificaram que a língua indígena ser-lhes-ia instrumento da mais alta valia, chave que lhes permitiria entrar em entendimento com os nativos das mais afastadas latitudes, pois era uma "língua geral" na costa do Brasil. Assim o Tupí assumiu, nos séculos XVI e XVII, grande importância social e econômica, nas relações entre europeus e índios, e também religiosa, porque foi o instrumento da catequese para os missionários tanto portugueses como franceses.

19. Se os colonos se limitaram a aprender o Tupí para satisfazer suas necessidades de intercâmbio social e econômico com os Tupinambá, os jesuítas, porém, dedicaram-se à melhor compreensão da língua, procurando registrar por escrito as suas formas, arrolando o vocabulário e registrando os fatos gramaticais. Por essa forma, logo dispuseram de elementos para ministrar ensinamentos mais ou menos sistematizados do Tupíaos novos missionários que sucessivamente vinham trabalhar no Brasil. A primeira gramática desta 
língua é da autoria do Pe. José de Anchieta; já era usada em 1556 e foi publicada em Coimbra; no ano de 1595, sob o título de "Arte de gramática da língua mais usada na Costa do Brasil". Já quase vinte anos antes, em 1578, tinham sido publicadas várias observações sobre a gramática tupi, pelo francês Jean de Léry, no final do original colóquio entre um tupinambá e um francês, acrescentado à célebre "Histoire d'un voyage fait en la terre du Brésil". As notas de Léry, porém, constituem apenas uma amostra da língua.

20. A gramática de Anchieta, "por ser o primeiro parto" (como dizia, em 1620, o Pe. M. Cardoso), é obscura e de difícil compreensão. Por essa razão, em fins de 1620 outro jesuíta, o Pe. Luís Figueira, tinha pronta para a imprensa a sua "Arte da Língua Brasílica", cuja primeira edição deve ser de 1621, elaborada segundo método "fácil, bem ordenado e breve", a fim de obviar as dificuldades da aprendizagem da língua com a obra de Anchieta. E que a "arte" de Figueira superou a de Anchieta, no fim a que se destinava, demonstra-o o fato de ter sido reeditada a de Figueira quatro vezes, durante o período colonial, enquanto que a de Anchieta não teve o privilégio de uma segunda edição, a não ser na segunda metade do século XIX, quando já não podia mais servir para fins práticos. Não obstante isso, o opúsculo de Anchieta ministra conhecimentos muito mais amplos e profundos, e mais precisos, que a de Figueira. É um trabalho resumido ou, melhor, condensado, o qual nos revela um autor dotado de privilegiado poder de observação. Apesar de preso à estreiteza de vista dos gramáticos de sua época, incapazes de estabelecer uma gramática que se não conformasse com os moldes gregos e latinos, Anchieta conseguiu superar as dificuldades da língua indígena, dedicando-se à sua descrição com muito empenho e todo cuidado, registrando minúcias e particularidades especialíssimas, anotando variantes de pronúncia e de forma, de maneira tal que nos leva a compará-la com um investigador moderno. Na exposição dos fenômenos fonéticos, detém-se Anchieta em quinze páginas, registrando, com meticulosidade rara mesmo em trabalhos modernos, mudanças e equivalências fonéticas, variantes individuais e diversidades dialetais. Só por aqui já se aquilata a excelência do trabalho de Anchieta, comparado com o de Figueira: este último dedica apenas pouco mais de uma página à fonética. Ambas as gramáticas, porém, são os melhores monumentos linguísticos que existem para o conhecimento do Tupí antigo.

21 Muitos vocabulários devem ter sido organizados pelos missionários, mas nenhum foi publicado durante o período da catequese. Por isso quase todos se perderam. Um, é verdade, foi publicado em meados do século XVII, mas não se destinava à aprendizagem da língua: o vocabulário de quase 300 palavras, organizado por Manuel de Morais, que João de Laet juntou à "História Natural do Brasil" de Jorge Macgrave (publicada em 1648). O maior vocabulário que se conservou em manuscrito é o "Vocabulário na Língua 
Brasílica”, de que foi publicada uma cópia datada de 1621, mas que deve pertencer ao século XVI, e cuja autoria é atribuída ao Pe. Leonardo do Vale; além de ser a melhor fonte para o conhecimento do léxico do Tupíantigo, fornece elementos subsidiários para a morfologia e a sintaxe da língua.

22. Para a catequese, os padres desde cedo traduziram para o Tupí o catecismo católico. Uma tradução é de autoria de Anchieta; teve duas edições, a primeira em 1618, a segunda em 1668 ("Doutrina cristã e mistérios da Fé, dispostos à moda de diálogo, em benefício dos índios catecúmenos”). Da $1^{\text {a }}$ ed. não se conhece nenhum exemplar, da $2^{\mathrm{a}}$ apenas um. Também em 1618 foi impressa, a $1^{\text {a }}$ ed. do "Catecismo na língua brasílica, etc.", "composto por padres doutos e bons línguas, da Companhia de Jesus" e ordenado e acrescentado pelo Pe. António de Araujo. Teve mais duas edições, em 1686 e em 1898 e, graças à última, é o mais conhecido atualmente. Ainda no séc. XVII foi publicado um terceiro catecismo: "Compêndio da doutrina cristã na língua portuguesa e brasílica, etc.” (1687), pelo Pe. João Felipe Bettendorf, missionário no Maranhão; foi reeditado em 1800. Textos de natureza religiosa, traduzidos para o Tupí, foram publicados pela primeira vez em 1575, na "Cosmographie Universelle” de Fr. André Thevet (Oração Dominical, Saudação Angélica, Símbolo dos Apóstolos).

23. Os jesuítas portugueses não se limitaram a escrever em Tupí os textos religiosos de que necessitavam, mas compuseram versos nesta língua, especialmente cantigas religiosas. Destaca-se sobretudo a obra do Pe. José de Anchieta, o qual, além de suas cantigas e poemetos bastante conhecidos, criou ainda um teatro em língua Tupí, de grande originalidade. Os versos obedeciam à técnica portuguesa, predominando a redondilha maior, e o assunto era normalmente religioso. A maior composição conhecida é o auto representado na festa de S. Lourenço, de Anchieta, com cerca de 1.500 versos, dos quais parte em espanhol e em português (em Tupí há cerca de 860 versos). Neste auto ocorrem episódios de sabor puramente indígena, o que lhe empresta um valor muito especial. "Como material para estudos filológicos e linguísticos, o texto tupi do Auto está acima de quaisquer encarecimentos pela sua extensão, antiguidade e pureza de língua" (Lemos Barbosa).

24. Para o conhecimento do Tupí antigo são indispensáveis as seguintes obras-fontes, assinaladas só dentre as publicadas e mais acessíveis:

\section{A. Gramáticas.}

1. Anchieta, Joseph de, Arte de gramática da língua mais usada na costa do Brasil, Coimbra, 1595 (São mais acessíveis as edições da Biblioteca Nacional do Rio de Janeiro - Rio, 1933 - e da Editora Anchieta - S. Paulo, 1946).

2. Figueira, Luís, Arte da língua brasílica, Lisboa (1621?). (Todas as edições são raras; as mais recentes são as de Júlio Platzmann (Gramática da língua do 
Brasil) - Lípsia, 1878 - e de Emilio Allain (Arte de gramática da língua brasílica)- Rio, (1880).

\section{B. Vocabulários}

3. Vocabulário na língua brasílica. Manuscrito português-tupi do século XVII (1621), coordenado e prefaciado por P. Ayrosa. Coleção do Departamento de Cultura, vol. XX, S. Paulo, 1938.

4. Castilho, Pero de, Nomes das partes do corpo humano pela língua do Brasil. Ed. de P. Ayrosa, Coleção do Departamento de Cultura, vol. XIV. S. Paulo, 1937.

5. Emanuel de Morais, Pequeno dicionário dos nomes e verbos da língua dos brasileiros principalmente comuns, in Marcgrave, Jorge, História Natural do Brasil, trad. de J. P. Magalhães, ed. do Museu Paulista. S. Paulo, 1942.

(Para o conhecimento do léxico há de recorrer-se também às obras dos viajantes, cronistas e naturalistas dos séculos XVI e XVII: Gabriel Soares de Sousa, Fernão Cardim, Pero Gandavo, Hans Staden, Anthony Knivet, André Thevet, Jean de Léry, Claude d'Abbeville, Ives d'Evreux, Jorge Marcgrave, Guilherme Piso, etc., bem como, é óbvio, aos textos adiante mencionados).

\section{Textos}

6. Araújo, António de, Catecismo na língua brasílica, Lisboa, 1618. (A edição mais recente é a de Júlio Platzmann Lípsia, 1898).

7. Bettendorff, João F., Compêndio da doutrina cristã na língua portuguesa e brasílica, Lisboa, 1687. (2 $2^{\mathrm{a}}$ ed. de Fr. Mariano da Conceição Vellozo - Lisboa, 1800).

8. Anchieta, Joseph de, Auto representado na festa de S. Lourenço. Peça trilíngue do séc. XVI, transcrita, comentada e traduzida, na parte tupi, por M. de L. de Paula Martins. Museu Paulista, Boletim I, Documentação Linguística, 1. S. Paulo, 1948.

9. Paula Martins, M. de L. de, Contribuição para o estudo do teatro tupi de Anchieta. Faculdade Filos., Ciências e Letras da Univ. de S. Paulo, boletim XXIV. S. Paulo, 1941.

10. Paula Martins, M. de L. de, Poesias tupis (séc. XVI). Faculd. de Filos., Ciências e Letras da Univ. de S. Paulo, boletim LI. S. Paulo, 1945.

11. Ayrosa, Plínio, Poemas brasílicos do Pe. Cristóvão Valente, S. J. (notas e tradução). Faculd. de Filos., Ciências e Letras da Univ. de S. Paulo, boletim XXIII. S. Paulo, 1941.

12. Ayrosa, Plínio, Orações e diálogos da doutrina cristã na língua brasílica. Faculd. de Filos., Ciências e Letras da Univ. de S. Paulo, boletim CVI. S. Paulo, 1950. 


\section{Outra língua Tupí-Guaraní conhecida no século XVII: o Guaraní}

25. Pouco depois de terem os portugueses entrado em contato com os Tupinambá, no litoral do Brasil, os espanhóis que penetraram no continente sul-americano, subindo o rio da Prata, encontraram, nas regiões cortadas pelos rios Uruguai, Paraguai, Paraná e Paranapanema, os índios Guaraní, os quais, constituindo muitas tribos, estendiam-se para leste até a costa atlântica, que ocupavam desde Cananéia até o Rio Grande do Sul. No século XVI eram conhecidos pelo nome Karijó ou Karió, o qual, já no século seguinte, entre os europeus, foi suplantado pelo nome Guaraní. Estes índios eram estreitamente aparentados aos Tupinambá, tanto cultural quanto linguisticamente. A sua língua, desde então conhecida por língua Guaraní, diferia da língua Tupímais em alguns aspectos fonéticos; o léxico, a morfologia e a sintaxe, grosso modo, concordavam quase inteiramente. Assim era possível a intercompreensão de um Tupinambá e um Karijó.

26. Os Guaraní eram mais numerosos especialmente na província de Guairá, isto é, na região compreendida entre os rios Tietê e Iguaçú, o rio Paraná e o meridiano de Tordesilhas. Os jesuítas fundaram suas primeiras missões em Guairá no ano de 1610 e, nestas, que se multiplicaram e desenvolveram muito, destacou-se o Pe. António Ruiz de Montoya, o qual em 1639, depois de ter estado cerca de 30 anos entre os Guaraní, publicou o notável "Tesoro de la lengua Guaraní" - o maior repertório léxico e fraseológico até hoje existente de qualquer língua tupí-guaraní -, logo seguido, no ano seguinte, da "Arte y vocabulario de la lengua Guaraní" e do "Catecismo de la lengua Guaraní”. Depois destas obras de Montoya, várias outras foram publicadas pelos jesuítas sobre o Guaraní, ou em Guaraní, principalmente na primeira metade do século XVIII.

\section{Línguas Tupí-Guaranís modernas - o Nheengatú e o Avanheém}

27. Atualmente são conhecidas mais de 50 línguas tupí-guaranís, isto é, línguas aparentadas com o Tupí e o Guaraní. A maioria delas é falada em território brasileiro, outras no Paraguai, na Bolívia, no Peru, na Guiana Francesa. Citam-se algumas mais conhecidas: Guajajara no rio Grajaú (Maranhão) e Tembé nos rios Capim e Acará-Pequeno (Pará); Tapirapé no rio Tapirapés, afluente do Araguaia; Kamaiurá e Auetê nas cabeceiras do rio Xíngu; Apiaká e Parintintin no alto Tapajós; Wiráféd ou "Tupí do Machado", no rio Machado, afluente do Madeira; Oiampí no rio Oiapoque; Omágua no baixo Ucaiali; Kokama no Ucaiali e no Napo; Guaraiú e Xiriguano na Bolívia; Mbyá no sul do Paraguai; Apapokuva no sul de Matogrosso; etc. As melhor conhecidas, entretanto, são as línguas que são continuação atual do antigo Tupí e do antigo Guaraní falados nas áreas de colonização, ou sejam, respectivamente, o Tupí e o Guaraní modernos. 
28. O Tupí moderno ou Nheéngatú é falado na Amazônia, especialmente na bacia do Rio Negro. Em consequência da ação dos missionários, que no Norte do Brasil se serviram do Tupí como língua de catequese mesmo junto a índios de outras línguas, é hoje o Nheéngatú língua de relação entre índios não-tupís, particularmente entre as numerosas tribos de índios Aruák e Tukano dos afluentes do Rio Negro. Os indígenas dessas tribos (Baré, Baníua, Tariano, etc., entre os Aruak; Tukano, Deçano, etc., entre os Tukano) falam sua própria língua no seio da tribo, mas para entender-se com outros índios ou com os civilizados, servem-se do Nheéngatú, idioma preferido dos caboclos do Rio Negro. Principalmente por esse fato, porque é falado por povos de outras línguas, está o Nheéngatú profundamente alterado em relação à antiga língua dos Tupinambá. O sistema morfológico e sintático do Tupí antigo sofreu radical simplificação: perdeu-se quase por completo o rico jogo de prefixos e sufixos, o que, além de empobrecimento morfológico, acarretou também grande alteração sintática. Demais, a sintaxe do Nheéngatú tem sofrido influência da sintaxe portuguesa e são comuns atualmente as frases decalcadas sobre frases portuguesas. A fonética também se modificou bastante, sendo seu traço mais característico o predomínio das vogais e semivogais sobre as consoantes.

29. A partir da segunda metade do século XIX, veem-se publicando gramáticas, vocabulários e textos em Nheéngatú. Em 1851, criou-se, no Seminário Episcopal do Pará, a cadeira de "língua brasílica", em que se ensinava Nheéngatú aos sacerdotes que se destinavam à catequese. Seu segundo "lente", o Cel. Correia de Faria, publicou, em 1858, um "Compêndio da língua brasílica", primeira gramática do Tupí moderno. Das obras depois publicadas, destacamse especialmente o "Curso de língua geral segundo Ollendorf, compreendendo o texto original de lendas tupís", do Gal. Couto de Magalhães (1876); a "Poranduba amazonense" - coleção de lendas e contos em Nheéngatú-, de Barbosa Rodrigues (1890); "Lendas em Nheengatú e em Português" de Brandão de Amorim (1928) e os "Vocabulários da língua geral" do Conde Ermano Stradelli (1929). Bastantes conhecidas são, entre outras várias, as gramáticas do Maj. Pedro L. Sympson (1877) e do Pe. Constantino Tastevin (ed. francesa, 1910; ed. portuguesa, 1923).

30. O Guaraní moderno ou Avánhee(n) é falado pela população rural do Paraguai e de algumas províncias do norte da Argentina, principalmente de Corrientes. Embora muito mais conservador, tanto fonética quanto morfologicamente, do que o Nheéngatú, o Avánhee( $n$ ) também se modificou bastante em relação ao Guaraní antigo. Nele se realizaram plenamente várias tendências fonéticas manifestas na língua registrada pelo Pe. Montoya, como a queda das consoantes finais e a transformação de $s \mathrm{em} h$. O sistema morfológico, apesar de um tanto desfalcado e alterado, conserva ainda seus traços característicos. Foneticamente distingue-se o Avánhee( $n$ ) pela nasalização e pelo grande pre- 
domínio dos vocábulos oxítonos, ao contrário do Nheéngatú, em que são mais comuns os paroxítonos. Como as populações que falam o Avánheen falam também o espanhol, tem este exercido sobre aquele considerável influência, tanto no léxico, como na morfologia e na sintaxe.

31. Inúmeras são as obras que se têm publicado sobre o Avánhee (n) ou em Avánhee (n), desde o séc. passado, tanto gramáticas e dicionários, como livros de natureza religiosa e as produções da "literatura guaraní". Os paraguaios e corrientinos que têm o Avánhee (n) por língua materna, são muito dados a poetar nesta língua, e incontáveis são os poetas que têm produzido originalmente em Avánhee(n), embora com mentalidade latina. Publicam-se no Paraguai jornais e revistas nesta língua. E são muitíssimo comuns as letras de músicas "guaranís" (guarânias, polcas, purahéi...), que se difundem em gravações pelo mundo todo. ${ }^{1}$

\section{Bibliografia}

Ayrosa, Plínio, Apontamentos para a bibliografia da língua tupi-guarani. Faculd. de

Filos., Ciências e Letras da Univ. de S. Paulo, boletim XXXIII. S. Paulo, 1943.

Fernandes, Florestan, A organização social dos Tupinambá. S.Paulo, s. d.

Lemos Barbosa, A., O auto de São Lourenço, sep. de "Verbum", t. VII, fase. 2. Rio, 1950. Lemos Barbosa, A., O "Vocabulário na Língua Brasílica". Serviço de Documentação do Minist. da Educação e Saúde. (Rio, 1948).

Leite, Serafim, S. J, História da Companhia de Jesus no Brasil, t. II. Lisboa - Rio, 1938. Loukotka, C., Les Langues de la famille Tupi-Guarani. Faculd. de Filos., Ciências e Letras da Univ. de S. Paulo, boletim CIV. S. Paulo, 1950.

Léry, Jean de, História de uma viagem à terra do Brasil, trad. de M. Lobato. S. Paulo, 1926.

Léry, Jean de, Viagem à terra do Brasil, trad. de S. Milliet, 2a. ed. S. Paulo, 1951.

Marcgrave, Jorge, História natural do Brasil, trad. de J. P. Magalhães. S. Paulo, 1942.

Métraux, Alfred, La civilisation matérielle des tribus Tupi-Guarani. Paris, 1928.

Métraux, Alfred, La religion des Tupinamba et ses rapports avec celle des autres tribus Tupi-Guarani. Paris, 1928.

Métraux, Alfred, The Tupinamba, in "Handbook of South American Indians “, vol. 3, pp. 95-133. Washington, 1948.

Métraux, Alfred, The Guarani, in "Handbook of South American Indians", vol. 3, pp. 69-94. Washington, 1948.

1. Observação. Por razões de imprensa, na grafia dos vocábulos tupís não se adotou inteiramente o sistema gráfico empregado no Curso de Tupí Antigo que o autor está dando na Faculdade. Observem-se as seguintes alterações: $e(n), i(n), u(n)=$ vogais nasais; $i=$ vogal e semivogal; $u$ vogal e semivogal; $x=$ fricativa palatal surda; $n h$ oclusiva naso-palatal. 
Soares de Sousa, Gabriel, Notícia do Brasil, 2 tomos. Biblioteca Histórica Brasileira, XVI. S. Paulo, s. d.

Thevet, André, Singularidades da França Antártica, trad. de Estêvão Pinto. S. Paulo, 1944.

Vocabulário na Língua Brasílica, manuscrito português-tupi do século XVII, coordenado e prefaciado por Plínio Ayrosa. S. Paulo, 1938. 